\title{
Endocrine function, morbidity, and mortality after surgery for craniopharyngioma
}

\author{
K R LYEN AND D B GRANT \\ The Hospital for Sick Children, Great Ormond Street, London
}

SUMMARY The records of 59 children with craniopharyngioma first treated between 1960 and 1980 were reviewed. There was a high incidence of postoperative growth hormone deficiency (43 of 43), andrenocorticotrophin deficiency (26 of 36), thyrotrophin deficiency (13 of 20), gonadotrophin deficiency (15 of 16), and diabetes insipidus ( 44 of 58). Fifteen patients have died: diabetes insipidus was a contributory factor in 5 patients who died within the first 4 months of surgery; and 8 further children died unexpectedly after the postoperative period, probably as a result of anterior pituitary insufficiency. In addition, hypopituitarism led to medical emergencies in 12, 9 of whom had symptomatic hypoglycaemia. These findings illustrate the high incidence of pituitary deficits which follow current methods for treating childhood craniopharyngioma, and the long-term risks associated with these deficits.

Several papers have been written about the clinical features and the surgical management of children with craniopharyngioma. ${ }^{1-4}$ However, reports describing the complications of the endocrine deficits which often follow current methods of surgical treatment are few. ${ }^{5-8}$ The outcome in 59 children with craniopharyngiomas who were first seen at this hospital between 1960 and 1980 is reviewed. We believe this paper illustrates some of the problems that can arise during the surgical and medical management.

\section{Patients and methods}

Patients. The records of all patients first seen between 1960 and 1980 with a diagnosis of craniopharyngioma were reviewed. Only patients who had initial surgical treatment at this hospital are included; patients referred for endocrine management after surgery elsewhere are excluded. Banna et al. ${ }^{3}$ have already described the presenting features of the cases seen before 1973 .

The following report is based on the findings in 59 children: in each the diagnosis was confirmed either by histological examination of resected tumour or by the finding of cholesterol crystals in fluid aspirated from a cystic tumour. There were 34 boys aged between 1 and 13.8 (mean 6.2 ) years at the time of diagnosis, and 25 girls aged between 2.6 and 15 (mean $7 \cdot 7$ ) years.
The surgical management of many of the patients was described by Shapiro et al. ${ }^{4}$ and is summarised in Table 1 . Twenty patients required at least 2 surgical procedures because of tumour recurrence, and 26 children received radiotherapy as well.

The average duration of follow-up was 7 years and 23 patients are still attending outpatient clinics. A further 9 patients are still alive but 12 have been lost to follow-up. Fifteen patients have died: the causes of death are discussed below.

Endocrine evaluation. Growth hormone (GH) and adrenocorticotrophin (ACTH) secretion were assessed by measuring plasma $\mathrm{GH}^{9}$ and cortisol ${ }^{10}$ during stimulation tests, generally after injection of insulin $(0.05 \mathrm{U} / \mathrm{kg})$ but in some cases after injection of glucagon $(0.1 \mathrm{mg} / \mathrm{kg})$ : in patients already

Table 1 Surgical procedures carried out in 59 children with craniopharyngioma

\begin{tabular}{lll}
\hline Type of procedure & No of children \\
\cline { 2 - 3 } & Given procedure & Given radiotherapy \\
\hline $\begin{array}{l}\text { Single resection of tumour } \\
\text { Repeat resection for tumour }\end{array}$ & 33 & 9 \\
$\begin{array}{l}\text { recurrence } \\
\begin{array}{l}\text { Aspiration and tumour } \\
\text { resection }\end{array}\end{array}$ & 5 & 9 \\
$\begin{array}{l}\text { Aspiration of cystic tumour } \\
\text { Ventricular drainage }\end{array}$ & 5 & 3 \\
\hline
\end{tabular}


receiving treatment with steroids the morning dose was omitted before the test. Thyroid-stimulating hormone (TSH) secretion was assessed by estimating plasma thyroxine (T4), ${ }^{11}$ and assaying TSH $^{12}$ after injection of $100 \mu \mathrm{g}$ thyrotrophin-releasing hormone (TRH). Gonadotrophin secretion was studied by measuring plasma luteinising hormone (LH) and follicle-stimulating hormone (FSH) ${ }^{13}$ after intravenous injection of $100 \mu \mathrm{g}$ luteinising hormonereleasing hormone (LH-RH).

All the tests were carried out at least 3 weeks after surgery and at a time when perioperative steroid therapy had been reduced to physiological levels: in most cases tests were performed several months, or even years, after surgery or radiotherapy. In some patients the tests of anterior pituitary function were repeated, generally after further surgery for tumour recurrence. The most recent results are given for these patients.

The diagnosis of diabetes insipidus was generally made on the basis of marked polyuria which responded to treatment with vasopressin, and formal tests of urine concentrating capacity were performed in only a few patients in whom symptoms were slight.

\section{Findings}

Endocrine deficits. In some of the early cases in this series no reliable tests of anterior pituitary function were available and few children had tests of pituitary function carried out before surgery. The postoperative endocrine results which are available are summarised in Table 2. All the children tested had subnormal GH responses to insulin or glucagon stimulation, and 26 of the 36 children tested had evidence of impaired ACTH secretion. TRH tests were performed in 20 children, in 13 of whom there was no appreciable rise in plasma TSH. Of the remaining 7 cases who did have an increased level of TSH, 4 were subsequently treated with L-thyroxine

Table 2 Documented postoperative endocrine deficits

\begin{tabular}{|c|c|c|}
\hline & & $\begin{array}{l}\text { Total patients } \\
\text { studied }\end{array}$ \\
\hline \multicolumn{3}{|l|}{ Growth hormone (mU/1) } \\
\hline Number of children with peak $<5$ & 34 & 43 \\
\hline Number of children with peak 5-10 & 9 & 43 \\
\hline \multicolumn{3}{|l|}{ Corticotrophin $(\mathrm{mU} / \mathrm{l})$} \\
\hline $\begin{array}{l}\text { Number of children with peak } \\
\text { plasma cortisol }<320\end{array}$ & 26 & 36 \\
\hline \multicolumn{3}{|l|}{ Thyroid-stimulating hormone $(\mathrm{mU} / \mathrm{l})$} \\
\hline $\begin{array}{l}\text { Number of children with peak } \\
\text { serum TSH }<3\end{array}$ & 13 & 20 \\
\hline \multicolumn{3}{|l|}{ Gonadotrophin $(\mathrm{mU} / \mathrm{l})$} \\
\hline $\begin{array}{l}\text { Number of children with peak } \\
\text { LH and FSH }<1\end{array}$ & 15 & 16 \\
\hline \multicolumn{3}{|l|}{ Vasopressin } \\
\hline $\begin{array}{l}\text { Number of children with clinical } \\
\text { diagnosis of diabetes insipidus }\end{array}$ & 44 & 58 \\
\hline
\end{tabular}

because of persistently low plasma T4 levels which suggested the presence of 'hypothalamic' hypothroidism. Plasma LH and FSH were measured after LH-RH injection in 16 patients (mean age $11 \cdot 1$ years) who showed no evidence of spontaneous pubertal development. One boy aged 8.6 years showed a peak $\mathrm{LH}$ value of $25 \mathrm{mU} / 1$ during the test but in the remaining 15 patients no rise was detectable in either LH or FSH.

Forty-four patients had persistent postoperative diabetes insipidus which required treatment with vasopressin.

Growth and pubertal development. Preoperative records of height were available in only 36 children: in 8 the height was more than 2 standard deviation (SD) scores below the mean, suggesting the presence of GH deficiency at the time of diagnosis. For the entire group, height was about 1 SD score below the mean.

Fourteen patients grew normally for variable periods (1 to 6 years) after surgery. GH levels were studied in 10 of them and peak values below $10 \mathrm{mU} / 1$ were found. In 8 of the 14 cases growth was associated with hyperphagia and pronounced obesity: these were not features in the remaining 6 cases, one of whom was a boy who developed precocious puberty.

In all, 31 patients have been treated with $\mathrm{GH}$ and the results for the children who have completed theiro treatment were reported by Burns et al. ${ }^{\mathbf{1 4}}$ Most? patients in this series have been given maintenance T4 and steroids: of the 23 cases still attending the outpatient clinics only 2 are not receiving T4 and all but one are taking cortisone or hydrocortisone at doses of 5 to $15 \mathrm{mg}$ daily.

With the exception of the boy with precocious puberty, none has shown spontaneous pubertal development; however 2 girls show good pubertal development. Five of the older boys have been treated with depot testosterone injections and 6 of the girls with ethinyl oestradiol.

Deaths. Fifteen patients are known to have died.

\section{Early postoperative death}

Only one child died as a direct result of an operative procedure. This 7-year-old girl suddenly collapsed about 6 hours after aspiration of a large cystic tumour: necropsy showed subarachnoid haemorrhage and 'coning' at the foramen magnum.

\section{Late postoperative deaths}

Five children had stormy courses after surgery and died within 4 months; 3 of these children had required surgery for tumour recurrence. All had diabetes insipidus, and difficulty in maintaining fluid 
balance probably played an important part in causing death. The condition of one 7-year-old girl deteriorated rapidly 24 hours after surgery as a result of uncontrolled diabetes insipidus and she died 2 days later without regaining consciousness. The condition of the other 4 deteriorated in the first few days after surgery; one developed a hemiparesis and another quadriplegia. Maintenance of fluid balance was difficult in these stuporose patients and recurrent episodes of hyponatraemia or hypernatraemia persisted until their deaths 1 to 4 months later. Necropsy in one showed infarction of the right frontal lobe with no sign of residual tumour.

\section{Tumour recurrence}

Although many patients required repeat surgical procedures because of tumour regrowth, only one child died as a direct result of recurrence. This was a girl who was blind and who had a hemiparesis after incomplete removal of a large tumour at age 6 years. Further attempts to remove the tumour were not felt to be justified and she died at age 12 years.

\section{Unexpected late deaths}

Eight children died unexpectedly 3 months to 8 years after surgery. The clinical details are shown in Table 3. In 2 cases few clinical details are available, but in 4 sudden collapse occurred after a respiratory infection, and in 2 after gastroenteritis. Social factors probably contributed to the deaths of 4 children: 3 came from very inadequate homes and the fourth was at boarding school where close medical supervision was difficult to achieve.

Emergency admissions to hospital. A total of 12 children required emergency admission to hospital as a result of pituitary insufficiency.

Nine patients were admitted to hospital with symptomatic hypoglycaemia. Their clinical features are summarised in Table 4. In 5 cases hypoglycaemia was precipitated by gastroenteritis and 2 further boys came from inadequate homes. One boy with
Table 3 Unexpected late deaths

\begin{tabular}{|c|c|c|c|c|c|}
\hline Age & Sex & $\begin{array}{l}\text { Time after } \\
\text { surgery } \\
\text { (years) }\end{array}$ & $\begin{array}{l}\text { Diabetes } \\
\text { insipidus }\end{array}$ & $\begin{array}{l}\text { Treatment } \\
\text { with } \\
\text { steroids }\end{array}$ & Comments \\
\hline $2 \cdot 7$ & $\mathbf{M}$ & 0.3 & Yes & Yes & Gastroenteritis* \\
\hline $3 \cdot 2$ & $\mathbf{M}$ & 0.4 & Yes & Yes & 'Sudden collapse'* \\
\hline $4 \cdot 7$ & M & $1 \cdot 5$ & No & Yes & $\begin{array}{l}\text { Respiratory } \\
\text { infection. } \\
\text { Hypoglycaemia }\end{array}$ \\
\hline $6 \cdot 0$ & $\mathbf{F}$ & $3 \cdot 0$ & No & Yes & Gastroenteritis \\
\hline $8 \cdot 9$ & $\mathbf{M}$ & $4 \cdot 5$ & No & Yes & $\begin{array}{l}\text { Respiratory } \\
\text { infection* }\end{array}$ \\
\hline 11.0 & $\mathbf{F}$ & 4.0 & Yes & No & 'Sudden collapse' \\
\hline $14 \cdot 3$ & $\mathbf{M}$ & $8 \cdot 8$ & Yes & No & $\begin{array}{c}\text { Respiratory } \\
\text { infection }\end{array}$ \\
\hline $15 \cdot 9$ & $\mathbf{M}$ & $2 \cdot 0$ & Yes & Yes & $\begin{array}{c}\text { Respiratory } \\
\text { infection }\end{array}$ \\
\hline
\end{tabular}

*Children from inadequate homes.

recurrent hypoglycaemia sustained severe brain damage with dementia, and another subsequently died after a respiratory infection at age 14 years. The other 7 cases made uneventful recoveries.

Three children with diabetes insipidus on treatment with desmopressin required emergency admission because of water overload which caused convulsions and drowsiness; 2 were boys from inadequate homes who on several occasions had been admitted with hyponatraemia, probably as a result of excessive drinking as part of behavioural disorders.

One 15-year-old boy was admitted with pneumonia and circulatory failure 10 years after his tumour had been resected. Postoperative tests had indicated normal ACTH secretion and he was not receiving steroid replacement therapy at the time of admission. He responded to vigorous treatment with antibiotics and steroids and is now on maintenance steroid therapy.

\section{Discussion}

This retrospective study has a number of limitations, particularly with regard to lack of uniformity in investigation and management. In addition, few of

Table 4 Admissions with hypoglycaemia

\begin{tabular}{|c|c|c|c|c|c|c|}
\hline \multirow[t]{2}{*}{ Age } & \multirow[t]{2}{*}{$\operatorname{Sex}$} & \multirow{2}{*}{$\begin{array}{l}\text { Time after } \\
\text { surgery (years) }\end{array}$} & \multirow{2}{*}{$\begin{array}{l}\text { Diabetes } \\
\text { insipidus }\end{array}$} & \multicolumn{2}{|l|}{ Treatment } & \multirow[t]{2}{*}{ Comments } \\
\hline & & & & With steroids & With $G H$ & \\
\hline $\begin{array}{r}5 \cdot 5 \\
5 \cdot 5 \\
5 \cdot 7 \\
6 \cdot 5 \\
8 \cdot 0 \\
9 \cdot 7 \\
9 \cdot 9 \\
10 \cdot 8 \\
11 \cdot 8\end{array}$ & $\begin{array}{l}\mathbf{M} \\
\mathbf{M} \\
\mathbf{M} \\
\mathbf{M} \\
\mathbf{F} \\
\mathbf{M} \\
\mathbf{F} \\
\mathbf{M} \\
\mathbf{F}\end{array}$ & $\begin{array}{r}2 \cdot 0 \\
1 \cdot 2 \\
2 \cdot 0 \\
0 \cdot 5 \\
2 \cdot 5 \\
3 \cdot 0 \\
0 \cdot 3 \\
5 \cdot 0 \\
10 \cdot 0\end{array}$ & $\begin{array}{l}\text { No } \\
\text { Yes } \\
\text { Yes } \\
\text { Yes } \\
\text { Yes } \\
\text { Yes } \\
\text { Yes } \\
\text { Yes } \\
\text { No }\end{array}$ & $\begin{array}{l}\text { Yes } \\
\text { Yes } \\
\text { Yes } \\
\text { Yes } \\
\text { Yes } \\
\text { Yes } \\
\text { No } \\
\text { No } \\
\text { Yes }\end{array}$ & $\begin{array}{l}\text { Yes } \\
\text { Yes } \\
\text { No } \\
\text { No } \\
\text { No } \\
\text { Yes } \\
\text { No } \\
\text { No } \\
\text { Yes }\end{array}$ & $\begin{array}{l}\text { Gastroenteritis } \\
\text { Gastroenteritis } \\
\text { Gastroenteritis } \\
\text { Inadequate home* } \\
\text { Otitis media* } \\
\text { Inadequate home* } \\
\text { Steroids stopped } \\
\text { Gastroenteritis } \\
\text { Gastroenteritis }\end{array}$ \\
\hline
\end{tabular}

*More than one episode. 
the patients had had detailed investigation of pituitary function before surgery, as most presented as neurosurgical emergencies with deteriorating vision or symptoms of raised intracranial pressure. However, roughly one-quarter had pronounced short stature at the time of diagnosis, suggesting that GH deficiency was already present. This is in accord with the experience of others-for example, more than half the patients investigated by Thomsett $\mathrm{et} \mathrm{al.}{ }^{7}$ and by Newman et $a l .^{8}$ had preoperative GH deficiency.

The high incidence of postoperative pituitary deficits in our series of patients is similar to that described by Thomsett et al. ${ }^{7}$ and Newman et al. ${ }^{8}$ In these last two series all patients had postoperative GH deficiency, $80-100 \%$ had ACTH deficiency, $80-85 \%$ TSH deficiency, 70-100\% gonadotrophin deficiency, and $70-72 \%$ diabetes insipidus. The respective figures for our patients are $100 \%$ for $\mathrm{GH}$ deficiency, $72 \%$ for ACTH, $65 \%$ for TSH, $93 \%$ for gonadotrophins, and $74 \%$ for diabetes insipidus.

It has long been known that an appreciable proportion of children with craniopharyngioma grow at a normal rate after surgery despite the apparent absence of GH secretion. ${ }^{15}$ The incidence of such cases in our series (14 of 59) is similar to that reported by Kenny et al. ${ }^{15}$ (3 of 10), by Job et al. ${ }^{5}$ (10 of 35), and by Thomsett et al. ${ }^{7}$ (7 of 39). As in other series, growth was often associated with obesity and hyperphagia. While it is known that postoperative growth is associated with normal serum somatomedin levels, ${ }^{16} 17$ the stimulus for somatomedin production is still a matter for debate. However, most children with craniopharyngioma grow poorly after surgery and GH with supplementary thyroid and sex hormones are required. ${ }^{14}$

Poorly controlled diabetes insipidus probably contributed to the deaths of 5 of our patients after surgery, possibly by leading to cerebral venous thrombosis. All these deaths took place before the introduction of the long-acting vasopressin analogue desmopressin. However, control of postoperative fluid balance is still a problem, particularly in patients with both diabetes insipidus and hypodypsia after surgery. Such hypodypsia occurred in at least 4 of our cases but in all but one child a normal sense of thirst was regained after some months. Inappropriate vasopressin release after surgery can also complicate postoperative management. ${ }^{18}$ We believe that this may have been present in some of our patients but we were unable to document it in our retrospective study of the postoperative fluid balance charts.

Diabetes insipidus caused few problems after the immediate postoperative period. Although 3 children required admission to hospital because of overhydration, this was largely because of inappropriate management at home. In contrast, anterior pituitary failure -in particular ACTH deficiency-probably led to most of the late medical emergencies. The importance of cortisol deficiency, and to a lesser extent of GH deficiency, in the aetiology of hypoglycaemia is well known and amply illustrated by the 9 children who developed symptomatic hypoglycaemia, often after gastroenteritis. Hypoglycaemia also occurred in one child who died unexpectedly: we do not know whether it was an important factor in any of the other unexpected deaths.

Between 1975 and 1980 most of the children attending the outpatient clinics were given steroid replacement therapy, even if the postoperative tests of pituitary function indicated normal ACTH secretion. Fairly low doses of cortisone acetate or hydrocortisone (5-15 mg/day) were given in order to avoid any inhibition of growth, particularly in children on GH treatment, and parents have been instructed to double or triple the dose of steroid during any illness or infection. The importance of avoiding long periods without food and of obtaining medical help if the child becomes drowsy or unresponsive has also been stressed. Even so, 2 children died unexpectedly during this period and 4 developed symptomatic hypoglycaemia. It is probably significant that 4 of these 6 children came from very inadequate families.

In conclusion, the current surgical treatment of childhood craniopharyngioma is followed by a very high incidence of anterior and posterior pituitary failure. The attendant risks of hypoglycaemia or sudden collapse place a heavy responsibility on the family and call for careful long-term medical supervision.

\section{References}

1 Matson D D, Crigler J F, Jr. Management of craniopharyngioma in childhood. $J$ Neurosurg $1969 ; 30$ : 377-90.

2 Hoff J T, Patterson R H, Jr. Craniopharyngiomas in children and adults. $J$ Neurosurg $1972 ; 36: 299-302$.

3 Banna M, Hoare $\mathbf{R}$ D, Stanley P, Till K. Craniopharyngioma in children. J Pediatr 1973; 83: 781-5.

4 Shapiro K, Till K, Grant D N. Craniopharyngiomas in childhood: a rational approach to treatment. $J$ Neurosurg 1979; 50: 617-23.

5 Job J C, Lambertz J, Sizonenko P-C, Rossier A. La croissance des enfants atteints de craniopharyngiome. Arch Fr Pediatr 1970; 27: 341-53.

6 Hoffman H J, Hendrick E B, Humphreys R P, Buncic J R, Armstrong D L, Jenkin R D T. Management of craniopharyngioma in children. $J$ Neurosurg $1977 ; 47: 218-27$.

7 Thomsett M J, Conte F A, Kaplan S L, Grumbach M M. Endocrine and neurologic outcome in childhood craniopharyngioma: review of effect of treatment in 42 patients. J Pediatr 1980; 97: 728-35. 
${ }^{8}$ Newman C B, Levine L S, New M I. Endocrine function in children with intrasellar and suprasellar neoplasms. Am J Dis Child 1981; 135: 259-62.

- Grant D B, Jackson D, Raiti S, Clayton B E. Comparison of serum growth hormone levels after Bovril and insulin stimulation. Arch Dis Child 1970; 45: 544-6.

10 Barnes N D, Joseph J M, Atherden S M, Clayton B E. Functional tests of adrenal axis in children with measurement of plasma cortisol by competitive protein binding. Arch Dis Child 1972; 47: 66-73.

11 Ryness J. The measurement of serum thyroxine in children. J Clin Pathol 1972; 25 : 726-9.

12 Jackson D, Vanderschueren-Lodewyckx M, Grant D B. Thyrotrophin estimation in diagnosis and treatment of childhood thyroid disorders. Arch Dis Child 1975; 50: 522-5.

13 Savage M O, Preece M A, et al. Gonadotrophin response to LH-RH in boys with delayed growth and adolescence. Arch Dis Child 1981; 56: 552-6.

14 Burns E C, Tanner J M, Preece M A, Cameron N. Growth hormone treatment in children with craniopharyngioma: final growth status. Clin Endocrinol $(O x f)$ 1981 ; 14: 587-95.

15 Kenny F M, Iturzaeta N F, Mintz D, et al. Iatrogenic hypopituitarism in craniopharyngioma: unexpected catch-up growth in three children. $J$ Pediatr 1968; 72: 766-75.

16 Finkelstein J W, Kream J, Ludan A, Hellman L. Sulfation factor (somatomedin): an explanation for continued growth in the absence of immunoassayable growth hormone in patients with hypothalamic tumors. J Clin Endocrinol Metab 1972; 35: 13-7.

17 Costin G, Kogut M D, Phillips L S, Daughaday W H. Craniopharyngioma: the role of insulin in promoting postoperative growth. J Clin Endocrinol Metab 1976; 42: 370-9.

18 Chapman S J, Neville B G R, Schurr P H. Craniopharyngioma in childhood; the nature and management of early postoperative fluid and electrolyte disturbance. Dev Med Child Neurol 1978; 20 : 598-604.

Correspondence to Dr D B Grant, The Hospital for Sick Children, Great Ormond Street, London WC1N 3JH.

Received 22 July 1982

\section{British Paediatric Association}

Annual meetings

1983 12-16 April York University

1984 10-14 April York University

1985 16-20 April York University

1986 15-19 April York University

1987 7-11 April York Unievrsity 